\title{
Kamilla Lozowska-Marcinkowska
}

Uniwersytet Medyczny im. Karola Marcinkowskiego

w Poznaniu

\section{Poradnictwo domowe na lamach wybranych czasopism kobiecych w dwudziestoleciu międzywojennym}

Czasopisma kobiece ukazujące się w Drugiej Rzeczypospolitej bardzo często w swojej linii programowej zawierały działy, rubryki bądź kąciki z poradami domowymi. Informacje dotyczące prowadzenia domu, zebrane $\mathrm{w}$ formie atrakcyjnych, konkretnych i przede wszystkim praktycznych porad, były cenione przez czytelniczki kobiecych periodyków. Udzielanie rad i edukowanie kobiet na łamach czasopism kobiecych miało na celu przede wszystkim ułatwienie im stworzenia wzorowego domu. Kluczem zaś do dobrego zorganizowania takiego domu była wiedza praktyczna, którą czytelniczki czerpały z ulubionych czasopism.

Analizę tematyki poświęconej prowadzeniu domu oparto na wybranych tytułach periodyków kobiecych, takich jak: „Dobra Gospodyni” (1928-1939), „Kobieta w Świecie i w Domu” (1925-1939), „Organizacja Gospodarstwa Domowego” (1927-1932), „Pani Domu” (1932-1939) ${ }^{1}$, „Praktyczna Pani Dobra Obywatelka" (1935-1939). Wybór tych czasopism jest nieprzypadkowy. Każde z wymienionych pism łączyła wspólna idea, mianowicie pomoc w prowadzeniu domu w mieście albo na wsi. Reprezentatywnym periodykiem dla wiejskich pań domu była „Dobra Gospodyni” ukazująca się w Poznaniu przez kilkanaście lat. Pierwszy jej numer na rynku prasowym pojawił się 22 marca 1928 r., ostatni zaś w roku 1939. Czasopismo to było organem Związku Kółek Włościanek, o czym informował podtytuł i ukazywało się też nakładem Związku. Helena Szlagowska w imieniu redakcji „Dobrej Gospodyni” oraz Zarządu Związku Kółek Włościanek w kilku zdaniach nakreśliła charakter miesięcznika:

Odtąd zrzeszenie Włościanek będzie miało swoją gazetę, z której zasięgać będą członkowie nie tylko rad i sposobów z zakresu swojej produkcji, a więc co do chowu inwentarza, sadownictwa, warzywnictwa, mleczarstwa, co do gotowania, prania, szycia i innych zajęć domowych - ale również co do wychowania dzieci, higieny, czyli zdrowotności, słowem wszystkiego, co wchodzi

\footnotetext{
${ }^{1}$ Kontynuacja czasopisma „Organizacja Gospodarstwa Domowego”.
} 
w zakres działalności kobiecej. [...] Każda z Włościanek znajdzie w tej swojej gazecie to, czego potrzebuje, żeby być dobrą gospodynią, dobrą matką córką i żoną - dobrą Polką - obywatelką swej ojczyzny, dobrą chrześcijanką-katoliczką. Każda do tego swego organu może się udać $\mathrm{z}$ zapytaniem o radę $\mathrm{w}$ trudnościach gospodarczych, w wątpliwościach różnych... ${ }^{2}$

W zamierzeniu redakcji „Dobra Gospodyni” nie miała być periodykiem poświęconym wyłącznie sprawom dotyczącym działalności Kół Włościanek. Wyraźnie została podkreślona strona poradnicza czasopisma. Pismo łączyło w zasadzie dwie funkcje - informatora $\mathrm{z}$ poradnikiem.

Z wymienionych tytułów „Kobieta w Świecie i w Domu” była najdłużej ukazującym się periodykiem kobiecym na rynku prasowym. Czasopismo wydawane przez prężnie działającą Spółkę Wydawniczą „Bluszcz” było typowym produktem skierowanym przede wszystkim do kobiety miejskiej, ułatwiającym jej prowadzenie domu. Ten „Dwutygodnik poświęcony życiu domowemu i modom" był jednym z wielu pism stworzonych przez koncern wydawniczy „Bluszcz”. Dużą popularnością cieszył się inny jego warszawski periodyk kobiecy „Praktyczna Pani - Dobra Obywatelka” ukazujący się od roku 1935 aż do końca trwania Drugiej Rzeczypospolitej. Pismo miało charakter poradnika, co zostało dodatkowo podkreślone przez redakcję:

Dzisiejszy, pierwszy numer naszego pisma, obfituje $\mathrm{z}$ natury rzeczy w artykuły oderwane, poniekąd programowe, artykuły mające na celu zapoznanie się z czytelnikami i wyjaśnienia im naszych zamiarów. W przyszłości strona praktyczna, rzeczowa naszego dwutygodnika będzie jednak przeważała, gdyż jakiekolwiek wyznajemy zasady, dom, rodzina, gospodarstwo są dla nas niezmiennie ważne ${ }^{3}$.

Zarówno „Kobieta w Świecie i w Domu”, jak i „Praktyczna Pani - Dobra Obywatelka" powstały z myślą o racjonalnej organizacji pracy domowej, ale nie tylko. W obydwu tytułach oprócz tematyki poradnictwa domowego czytelniczki otrzymywały informacje charakterystyczne dla struktury typowego pisma kobiecego. Jednak nie na tym polegała nowatorskość tych periodyków. Nowością na rynku prasowym było połączenie problematyki prowadzenia domu miejskiego ze specyfiką zarządzania domem na wsi. Wydawałoby się, że są to elementy nie korespondujące ze sobą, jednak w obliczu popularności obu tytułów skutecznie konkurujące $\mathrm{z}$ innymi pismami o tej tematyce, w perspektywie czasu okazało się to dobrym posunięciem marketingowym ze strony koncernu Towarzystwa Wydawniczego „Bluszcz”“.

\footnotetext{
${ }^{2}$ H. Szlagowska, Powitanie, „Dobra Gospodyni” 1928, nr 1, s. 1.

${ }^{3}$ Wiadomości kulinarne, „Praktyczna Pani - Dobra Obywatelka” 1935, nr 1, s. 19. Należy podkreślić, że pismo początkowo ukazywało się jako ilustrowany dwutygodnik (10. i 25. dnia każdego miesiąca), następnie przekształciło się w tygodnik.

${ }^{4}$ Z. Zaleska, Czasopisma kobiece w Polsce; Materiaty do historii czasopism rok 1918-1937, Warszawa 1938, s. 207-208, 233. Zofia Zaleska w swojej pracy podkreśliła jeszcze fakt, że
} 
Periodykami, dla których sprawy prowadzenia gospodarstwa domowego w środowisku miejskim oraz wiejskim stanowiły najważniejsze, kluczowe treści, były przede wszystkim dwa stołeczne pisma: „Organizacja Gospodarstwa Domowego" i „Pani Domu”. Zofia Zaleska wspomniała w swojej pracy, że dzięki inicjatywie Aleksandry Grzybowskiej - przewodniczącej Stowarzyszenia Zjednoczonych Ziemianek - w trakcie zebrań dotyczących racjonalnej organizacji pracy domowej pojawił się pomysł założenia wydawnictwa poświęconego tej tematyce. Pomysł zmaterializował się w roku 1927 pod nazwą „Organizacja Gospodarstwa Domowego". Wydawnictwo utworzono przy sekcji gospodarstwa domowego w Instytucie Naukowej Organizacji. Po kilku latach nastapiła zmiana tytułu na „Pani Domu” i jednocześnie tematyczne poszerzenie zawartości treści. Pismo wychodziło jako organ Związku Pań Domu i Instytutu Gospodarstwa Domowego. Możemy te periodyki określić jako pisma z misją, ponieważ ich naczelnym celem było propagowanie wśród czytelniczek racjonalnych metod pracy w domu, mających podnieść poziom kultury domów polskich. Niezależnie od światopoglądu, sytuacji osobistej czy zawodowej kobiety, każda z kobiet prowadziła gospodarstwo domowe. Nawet te, które było stać na opłacanie służby i tak musiały wydawać polecenia i czuwać nad ogniskiem domowym. Pewien rodzaj obowiązków wynikających z zajmowania się domem dotyczył wszystkich kobiet. Właśnie takie argumenty zostały przywołane przez Marię Romanową w pierwszym numerze „Organizacji Gospodarstwa Domowego”. Co więcej, Romanowa dobitnie wyjaśniła, dlaczego na kobiecie jako „kierowniczce domu" spoczywała tak duża odpowiedzialność:

Z rozmieszczenia pokoi, ustawienia mebli, jakości służby i innych ledwo dostrzegalnych drobiazgów można wnioskować o jej poczuciu odpowiedzialności, rodzaju inteligencji, zainteresowaniach i upodobaniach. Jakiż nastrój w nim panuje? Zasadniczym jego rysem jest harmonia i pogoda. [...] Aby wytworzyć taką właśnie atmosferę trzeba ze strony pani domu pełnej świadomości celów, dokładnego zrozumienia specyficznych warunków życia rodziny i konsekwencji w każdem poszczególnem zarządzeniu. Dom pełen spokoju i ładu jest świadectwem owocnego wysiłku kierowniczki, wyrazem jej poważnego sposobu myślenia, gdy chodzi o ognisko domowe, wywołując obraz czarodziejki-gospodyni. Zaiste, wielkiego serca, jasnego umysłu i niezmordowanej wytrwałości trzeba, by dom rodzinny dawał każdemu radość, wypoczynek i schronienie. Przeciwnie, dom utrzymany niestarannie, w którym posiłki stale się spóźniają, a rozkazy, rzucane służbie, krzyżują się nawzajem, gdzie wszyscy pędzą z zawrotną szybkością, a nigdy na czas zdążyć i nic w porę zrobić nie mogą - zaciera sylwetkę najmilszej nawet kobiety nim rządzącej i pozostawia tylko chęć ucieczki od tego nieprodukcyjnego rozpędu i ogólnego niepokoju ${ }^{6}$.

\footnotetext{
„Praktyczna Pani - Dobra Obywatelka” była odpowiedzią na popularny żniński periodyk kobiecy - „Moją Przyjaciółkę”, który zresztą skutecznie konkurował z pismami stołecznymi.

${ }^{5}$ Tamże, s. 209.

${ }^{6}$ M. Romanowa, Znaczenie ogniska domowego, „Organizacja Gospodarstwa Domowego” 1927, nr 1, s. 1-2.
} 
Powyższe słowa uwidaczniają ówczesny punkt widzenia na pracę pani domu. W analizowanych periodykach kobiecych dosyć często podkreślano, że zadania i kompetencje kobiety zarządzającej swoim domem musiały być rozległe. Przykładna gospodyni to taka, która potrafiła racjonalnie kierować i zarządzać gospodarstwem domowym. Modną ideą w okresie dwudziestolecia międzywojennego było przekonywanie kobiet, że dom był niczym małe przedsiębiorstwo. Aby mogło ono sprawnie i efektywnie funkcjonować, musiało opierać się na solidnych, czyli racjonalnych i ekonomicznych podstawach. Na łamach czasopism kobiecych przekonywano czytelniczki, że te same zasady dotyczące naukowej organizacji pracy $\mathrm{w}$ wielkim przemyśle powinny również zostać zastosowane przez nie przy prowadzeniu własnego domu ${ }^{7}$. W „Praktycznej Pani - Dobrej Obywatelce" mowa jest nawet o posiadaniu własnego biura przez panią domu, skoro jej obowiązkiem było wywiązywanie się z funkcji administracyjnych. W najmniej okazałym wariancie takie biuro sprowadzało się do korzystania z biurka albo przynajmniej najmniejszego stolika, który będzie spełniał jego funkcję. Miało to być miejsce, do którego tylko ona będzie miała dostęp. Oprócz biurka pani domu potrzebowała jeszcze odpowiednich „,pomocy biurowych”, m. in.: ołówka chemicznego (czyli kopiowego, używanego w rachunkowości) do pokwitowań, kolorowego ołówka do podkreśleń, pióra i atramentu, gumki, niewielkiego bloku z wyrywanymi kartkami, na których będzie wypisywała codziennie polecenia dla pracowników. Ponadto powinna posiadać księgę rachunkowa, kalendarz ze spisem sezonowych prac gospodarskich, segregator do kwitów, książkę kucharską z alfabetycznym spisem potraw. Nie mogło w jej biurku zabraknąć także teczki na korespondencję, ponieważ

$\mathrm{w}$ teczce przechowuje się papier listowy, znaczki pocztowe miejskie i zamiejscowe oraz dwa kartony z listami. W jednym kartonie zatrzymuje się korespondencję, na która się jeszcze nie odpisało i na wierzchu kartonu kładzie się napis „,do odpowiedzi”. W drugi karton odkłada się listy załatwione - i takim też napisem opatruje się wierzch kartonu ${ }^{8}$.

Kiedy pani domu nabierze biegłości w administrowaniu domem, powinna wówczas swoje biuro uzupełnić jeszcze o kartotekę domowników ze specjalnym działem obowiązków towarzyskich. W kartotece domowników znajdą się informacje dotyczące „stanu posiadania, potrzeb i planowanych oraz realizowanych zaopatrzeń każdego członka rodziny", dzięki której wydatki na wszystkich domowników, jak i na każdego z osobna, będą sprawiedliwe. $Z$ kolei w satysfakcjonującym oraz kulturalnym wypełnianiu obowiązków towarzyskich pomoże pani domu kalendarzyk, w którym będą zaznaczone imieniny osób

${ }^{7}$ A. Janiak-Jasińska, Unowocześnianie gospodarstwa domowego $i$ wyposażenia mieszkań w Polsce międzywojennej, [w:] Równe prawa i nierówne szanse; Kobiety w Polsce międzywojen$n e j$, red. A. Żarnowska, A. Szwarc, Warszawa 2000, s. 196.

${ }^{8}$ M. Ankiewiczowa, Chcę być dobra gospodyniq: Biuro pani domu, „Praktyczna Pani - Dobra Obywatelka" 1939, nr 24, s. 13. Skan 9347.

${ }^{9}$ Tamże, s. 13. Skan 9347. 
z rodziny, przyjaciół i znajomych. Znajdzie się w nim również wykaz złożonych wizyt oraz rewizyt, a także spis prezentów imieninowych, jakie dostała pani domu i jej rodzina oraz nazwiska darczyńców.

Kluczem do dobrego zarządzania domem była z pewnością księga rachunkowa. Niezależnie od tego, czy pani domu mieszkała w mieście czy na wsi, musiała mieć książkę rachunkową, w której na bieżąco notowała wydatki. Z pouczających artykułów czytelniczki dowiadywały się, w jaki sposób należy ją prowadzić, by bezproblemowo pokonać meandry domowego budżetu. Podkreślano przede wszystkim konieczność racjonalnego skonstruowania tej księgi. Powinna ona zatem w sposób przejrzysty pokazywać stan finansowy gospodarstwa, czyli uwzględniać dochody i rozchody. Wydatki domowe należało zaszeregować do czterech podstawowych działów, takich jak wydatki żywnościowe, mieszkaniowe, ubraniowe oraz tzw. różne. Pani domu z książki rachunkowej powinna mieć zaś obraz codziennej i miesięcznej sumy wydatków każdego z tych działów ${ }^{10}$. Książka obrazowała też szczegółowo wydatki dnia oraz dawała zestawienie miesięczne rozchodów ogólnych, każdego działu i każdej rubryki. To zaś miało znaczenie dydaktyczne, ponieważ panie domu dowiadywały się z niej, czy działy były równomiernie obciążone wydatkami, czy też do niektórych zakradła się zbytnia rozrzutność w stosunku do dochodów ${ }^{11}$.

Prowadzenie książki rachunkowej przez wiejską panią domu pozwalało jej na dokonanie szybkiej oceny, czy dana dziedzina prowadzonego przez nia gospodarstwa była dochodowa czy też przynosiła zyski nieproporcjonalne do poniesionych kosztów. Albo odwrotnie, jaką dziedzinę produkcji powinna jeszcze bardziej rozszerzyć, skoro była ona źródłem największych zysków. Książka rachunkowa wiejskich gospodyń miała następujące działy: prowadzenie domu, ogród, hodowla zwierząt (najczęściej drobiu) oraz księga kasy ${ }^{12}$. Działy ogród i hodowla były działami zysku, natomiast dział pierwszy (prowadzenie domu $)^{13}$ wiązał się tylko z wydatkami. Na łamach „Dobrej Gospodyni” przypominano czytelniczkom, że najważniejsza jest skrupulatność i systematyczność w prowadzeniu księgi rachunkowej. Za największy błąd uważano notowanie „przychodów i rozchodów pieniężnych” po upływie kilku bądź kilkunastu dni. Stąd się brały „niedobory lub nadwyżki kasowe”, więc tego typu informacje należało zapisywać w księdze rachunkowej niezwłocznie ${ }^{14}$.

\footnotetext{
${ }^{10}$ Każdy dział dzielił się na poszczególne rubryki (np. dział żywnościowy na różne rodzaje pokarmów: nabiał, warzywa, mięso itp.).

${ }^{11}$ H. Przesmycka, O prowadzeniu domowych rachunków, „Organizacja Gospodarstwa Domowego" 1927, nr 9, s. 107-108.

${ }^{12}$ Rachunkowość w wiejskiem gospodarstwie kobiecem, „Organizacja Gospodarstwa Domowego" 1927 , nr 8, s. 95.

${ }^{13}$ Sposób prowadzenia rachunków domowych przez wiejską panią domu rządził się takimi samymi prawami, jak w przypadku prowadzenia domu w mieście.

${ }^{14}$ M. Rolbiecki, Uwagi na tle konkursu rachunkowości gospodarstwa domowego, „Dobra Gospodyni” 1932, nr 6, s. 2. Skan 8839.
} 
Poradnictwo domowe w omawianych periodykach dotyczyło przede wszystkim takich zagadnień, jak: gotowanie, aranżacja mieszkań, pielęgnacja roślin doniczkowych, hodowla zwierząt, ogrodnictwo i sadownictwo czy kultura towarzyska. Redakcje pism kobiecych ,pochylały się” nad najbardziej prozaicznymi problemami związanymi $\mathrm{z}$ prowadzeniem gospodarstwa domowego, ponieważ stanowiły one nieodłączną codzienność każdej pani domu. Było zatem miejsce na omówienie problemów związanych z nakrywaniem do stołu, układaniem jadłospisu, przyjmowaniem gości, zarówno tych zaproszonych, jak i niespodziewanych. Niewątpliwie sprawdzian zdolności kulinarnych oraz kultury pani domu stanowiło organizowanie przyjęć. Dlatego zamieszczane na łamach periodyków rady nie ograniczały się wyłącznie do ciekawych propozycji kulinarnych. Oprócz smacznych potraw, umiejętnie pokrojonych i podanych ryb oraz mięs ${ }^{15}$, ważna była estetyka ich przygotowania, a także podania ${ }^{16}$. Zachęcano więc kobiety nie tylko do dekorowania potraw ${ }^{17}$ ale także do eleganckiego nakrywania stołu. W przypadku przyjęć wieczornych, o charakterze uroczystym ,przeznaczonym do zgrupowania strojnej rzeszy gości", istniały sztywne reguły, od których przykładnym paniom domu odstępować nie wypadało. Efekt wykwintnie nakrytego stołu zapewniała:

Bielizna nieskazitelnie biała, o gładkiej, lśniącej powierzchni, inkrustowana koronkami, czy też bogato ręcznie mereżkowana; porcelana biała, ujęta w minjaturowe złociste obrzeżenie, znaczona monogramami. Grube, rżnięte szkła lub kryształy, pośrodku stołu waza porcelanowa, kryształowa, szklana, ustawiona na podłożu tafli lustrzanej, a w niej bogactwo róż o nikłych tonach. Serwetki niewielkie, ułożone zgrabnie na talerzach, oświetlenie górne lub też stylowe kandelabry ${ }^{18}$.

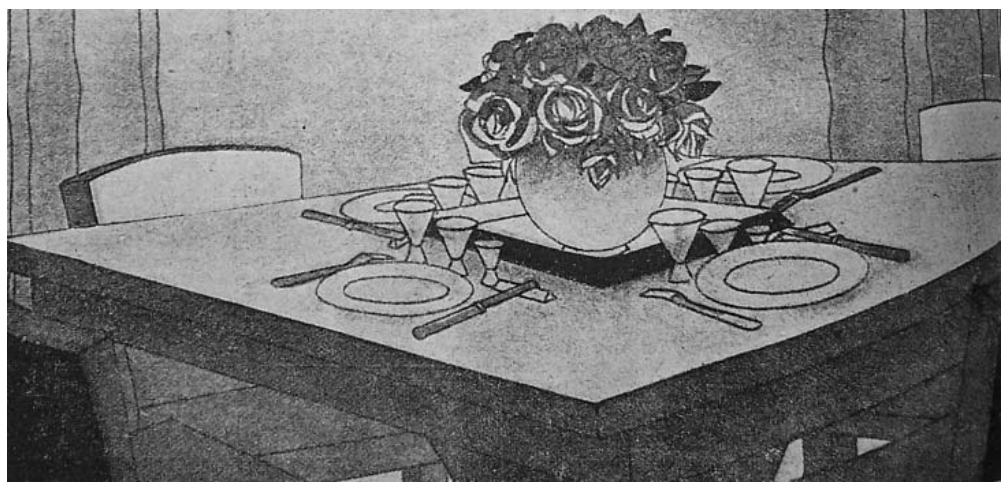

Ryc. 1. Propozycja nakrycia stołu dla oficjalnych gości.

Rozmaite nakrycia, „Kobieta w Świecie i w Domu” 1929, nr 8, s. 14

${ }^{15}$ Dobra Gospodyni, Dzielenie mięsa i ryb, „Kobieta w Świecie i w Domu” 1930, nr 3, s. $11-12$.

${ }^{16}$ M. D., Estetyka gotowania, „Kobieta w Świecie i w Domu” 1930, nr 3, s. 16-18. Skan 9687.

${ }^{17}$ M. Słomkówna, Teorja dekoracji potraw; Dekoracja pótmisków z potrawami zimnymi i goracymi, „Praktyczna Pani - Dobra Obywatelka” 1939, nr 3, s. 17. Skan 9184.

${ }^{18}$ Stót jadalny, „Kobieta w Świecie i w Domu” 1928, nr 20, s. 14. Skan 9521. 
Warto podkreślić, że propagowanie na łamach periodyków eleganckiego sposobu nakrywania stołu nie dotyczyło wyłącznie oficjalnych spotkań towarzyskich. Podkreślano, że kultura jedzenia obowiązuje także w sytuacjach codziennych i mniej uroczystych. Zdjęcie poniżej (ryc. 2) prezentuje propozycję skromnie, a zarazem estetycznie nakrytego stołu dla dwojga bez specjalnej okazji:

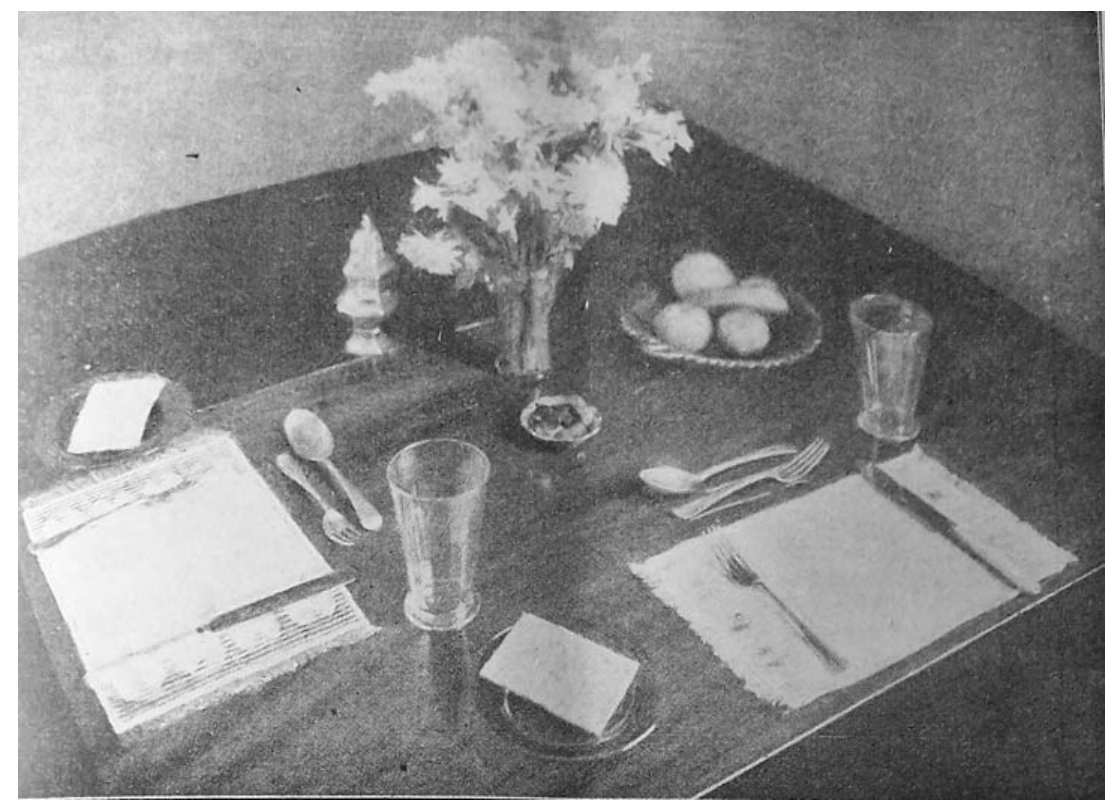

Ryc. 2. Najmodniejsze nakrycie stołu, „Kobieta w Świecie i w Domu” 1930, nr 8, s. 11

Na łamach „Dobrej Gospodyni”, „Kobiety w Świecie i w Domu” czy „Praktycznej Pani - Dobrej Obywatelki" pojawiło się niemało artykułów poświęconych kulturze przyjęć i spotkań towarzyskich. Wskazówki dotyczące bon tonu przeznaczone były nie tylko dla pań domu, ale również dla ich rodzin. Toteż, aby uniknąć towarzyskich potknięć, które mogły stać się powodem ochłodzenia kontaktów, namawiano czytelniczki do krytycznego przyjrzenia się zarówno manierom swoim, jak i pozostałych domowników. Podkreślano, że posiadanie ogłady towarzyskiej zapewniało komfortowe samopoczucie i pewność siebie w każdej sytuacji, nawet w przypadku najbardziej wytwornych przyjęć. Za nieeleganckie, nie licujące $\mathrm{z}$ dobrym wychowaniem, zostały uznane następujące zachowania: opieranie rąk na stole podczas jedzenia, wkładanie noża do ust, nakładanie dużych porcji na talerz i zostawianie ich niezjedzonych, oblizywanie palców, dmuchanie na gorącą zupę, mlaskanie czy siorbanie ${ }^{19}$, także ziewanie,

\footnotetext{
${ }^{19}$ Kilka uwag o dobrem wychowaniu, „Dobra Gospodyni” 1928, nr 6, s. 43.
} 
połykanie za dużych kawałków jedzenia czy używanie palców zamiast noża ${ }^{20}$. Szczegółowo zostały również opisane zasady dotyczące składania wizyt rodzinie, znajomym czy sąsiadom, aby i w tej materii pani domu mogła uchodzić za obytą ,z wymaganiami światowego kodeksu”21. Dziennikarka wypowiadająca się pod pseudonimem Dobra Gospodyni uczulała czytelniczki na fakt, że nie ma znaczenia stopień zażyłości z gospodarzami przyjęcia, ponieważ pewne formy zachowania są niezmienne:

wizyty bywają etykietalne lub serdeczne. Tak w pierwszych, jak w drugich, trzeba przestrzegać form i zwyczai towarzyskich, bo choć byśmy znali bardzo dobrze gospodarzy, goście ich, mniej lub więcej nam obcy, widząc nasze zbyt swobodne zachowanie, mogliby przypuścić, że ich lekceważymy ${ }^{22}$.

Autorka artykułu temat wizyt potraktowała dogłębnie i obszernie opisała meandry towarzyskich spotkań. Wyodrębniła kategorie wizyt, mianowicie pierwsza wizyta jako najważniejsza, wizyta po zaproszeniu, kondolencyjna, dziękczynna i z życzeniami oraz opisała prawidłowe zachowania dla nich charakterystyczne.

Powszechne dla redakcji periodyków kobiecych było zamieszczanie w każdym numerze przepisów kulinarnych. Tworzenie książki kucharskiej w odcinkach miało niebagatelne znaczenie zwłaszcza dla początkujących gospodyń domowych, które nie zdążyły jeszcze stworzyć własnego warsztatu kucharskiego. W związku z tym, wiedzy i natchnienia szukały w sprawdzonych przepisach. Korzystały z nich jednak nie tylko one. Nawet kobiety mające doświadczenie w gotowaniu chętnie sieggały po nowe pomysły na codzienny lub uroczysty obiad czy kolację. Liczba dni w roku kalendarzowym jest pokaźna, więc tym bardziej urozmaicone posiłki były doceniane przez wszystkich domowników. W dobie wielkiego kryzysu zwracano uwagę na komponowanie posiłków nie tylko zdrowych i pożywnych, ale także tanich. Przykładem może być kilka wariacji obiadowych zaproponowanych na łamach „Pani Domu”. Jedną z takich propozycji był dwudaniowy obiad $\mathrm{z}$ deserem składający się z blinów z masłem i śmietaną albo sałatki śledziowej. Do tego barszcz zabielany $z$ uszkami z grzybów, sandacz z sosem pieczarkowym lub korniszonowym oraz krem mandarynkowy bądź puree $\mathrm{z}$ jabłek $^{23}$. Korzystanie $\mathrm{z}$ jadłospisów tygodniowych oszczędzało czas, ułatwiało również planowanie zakupów i wydatków, a to

${ }^{20}$ Dobra Gospodyni, O poprawnem zachowaniu się przy jedzeniu, „Kobieta w Świecie i w Domu" 1928, nr 21, s. 12.

${ }^{21}$ Wizyty i rewizyty, „Kobieta w Świecie i w Domu” 1928, nr 24, s. 18.

${ }^{22}$ Dobra Gospodyni, O wizytach i przyjęciach, „Kobieta w Świecie i w Domu” 1929, nr 4, s. 13. Zob. K. Hojnacka, Przyjęcia a formy towarzyskie, „Pani Domu” 1939, nr 1, s. 6-7.

${ }^{23}$ M. Karczewska, Obiady zdrowe, niedrogie, tatwe i smaczne, „Pani Domu” 19, nr 1932, s. 16 . 
z kolei usprawniało administrowanie domem. Pożyteczną umiejętnością było także robienie wina, którym mogła gospodyni poczęstować gości. Na łamach pism kobiecych propagowano $\mathrm{w}$ ten sposób zastąpienie mocnych alkoholi albo drogich win zagranicznych samodzielnie wyprodukowanymi. Sposób produkcji domowego wina pojawiał się kilkakrotnie na łamach różnych pisma kobiecych. Poza tym został na tyle szczegółowo omówiony, aby mógł spełnić funkcję instruktażową nawet dla początkujących pań domu ${ }^{24}$.

Niedoświadczonym paniom domu, które od niedawna prowadziły własne gospodarstwa domowe, sporą trudność sprawiało rozróżnianie rodzajów mięsa i przygotowanie $\mathrm{z}$ nich potraw. W związku $\mathrm{z}$ tym redakcje kilku pism zamieszczały wskazówki mające przedstawić sposoby domowego oprawiania zwierząt hodowlanych. Czytelniczki „Kobiety w Świecie i w Domu” a zwłaszcza „młode gosposie", bo do nich autorka poradnikowego artykułu go kierowała, zostały poinstruowane, jakimi kategoriami powinny kierować się przy wyborze kurczęcia na ubój oraz jak należy przygotować ptaka do dalszej obróbki kulinarnej:

Przede wszystkiem trzeba, aby kurczę było tłuste, w dobrym gatunku, bo z chudego, byle jakiego drobiu nigdy nic dobrego nie da się przyrządzić. Czy kurczę tłuste - poznajemy rozdmuchując mu piórka: jeżeli jest białe - będzie smaczne; sino-czerwonego nie kupujmy pod żadnym pozorem. Poza tem trzeba umieć zastosować wiek kurczaka do jego przyprawienia. Sześciotygodniowe kurczątko doskonałe jest smażone lub pieczone na ruszcie; dziesięciotygodniowe - najlepsze do pieczenia na rożnie; ze starszego - zrobimy wyborną potrawkę. Po zarżnięciu kuraka trzeba, póki ciepły, zanurzyć go w zimnej wodzie z kawałkiem lodu, aby skruszał, trzymając go w niej do trzech godzin, stosownie do wieku: im młodszy tem krócej. Po wyjęciu, wytrzeć do sucha czystą serwetką i zaraz skubać ostrożnie, aby nie pozdzierać skórki; szypułki starannie usunąc końcem igły, a całego kurczaka z wierzchu i ze środka wytrzeć sokiem z cytryny dla nadania mu białości i smaku ${ }^{25}$.

W dalszej części artykułu opatrzonego instruktażowymi zdjęciami zostały podane również różnorodne sposoby przyrządzania potraw z drobiu. Kolejnym problemem dla niedoświadczonej pani domu było oprawianie wieprza i przygotowanie z niego wyrobów. Informacje na ten temat niejednokrotnie były zamieszczane na prośbę samych czytelniczek. Analogicznie do artykułu na temat oprawiania drobiu i w tym przypadku czytelniczki otrzymały szczegółowy

${ }^{24}$ Wina owocowe, „Dobra Gospodyni” 1928, nr 5, s. 36-37; Jeszcze o winach owocowych, „Dobra Gospodyni” 1928, nr 6, s. 46-47; Scabiosa, Wina owocowe, „Kobieta w Świecie i w Domu” 1929, nr 12, s. 14; Scabiosa, Wina owocowe (dokończenie), „Kobieta w Świecie i w Domu” 1929, nr 14, s. 16; Wino z agrestu, „Praktyczna Pani - Dobra Obywatelka” 1939, nr 25, s. 24-25; Wina owocowe, „Praktyczna Pani - Dobra Obywatelka” 1939, nr 30, s. 21; Wina domowe, „Praktyczna Pani - Dobra Obywatelka” 1937, nr 30, s. 19.

${ }^{25}$ Dobra Gospodyni, Kurczęta, „Kobieta w Świecie i w Domu” 1928, nr 10, s. 12. 
opis koniecznych czynności ${ }^{26}$. Dla ułatwienia oprawiania mięsa została zamieszczona ilustracja ułatwiająca rozróżnienie poszczególnych części tuszy wieprzowej (ryc. 3):

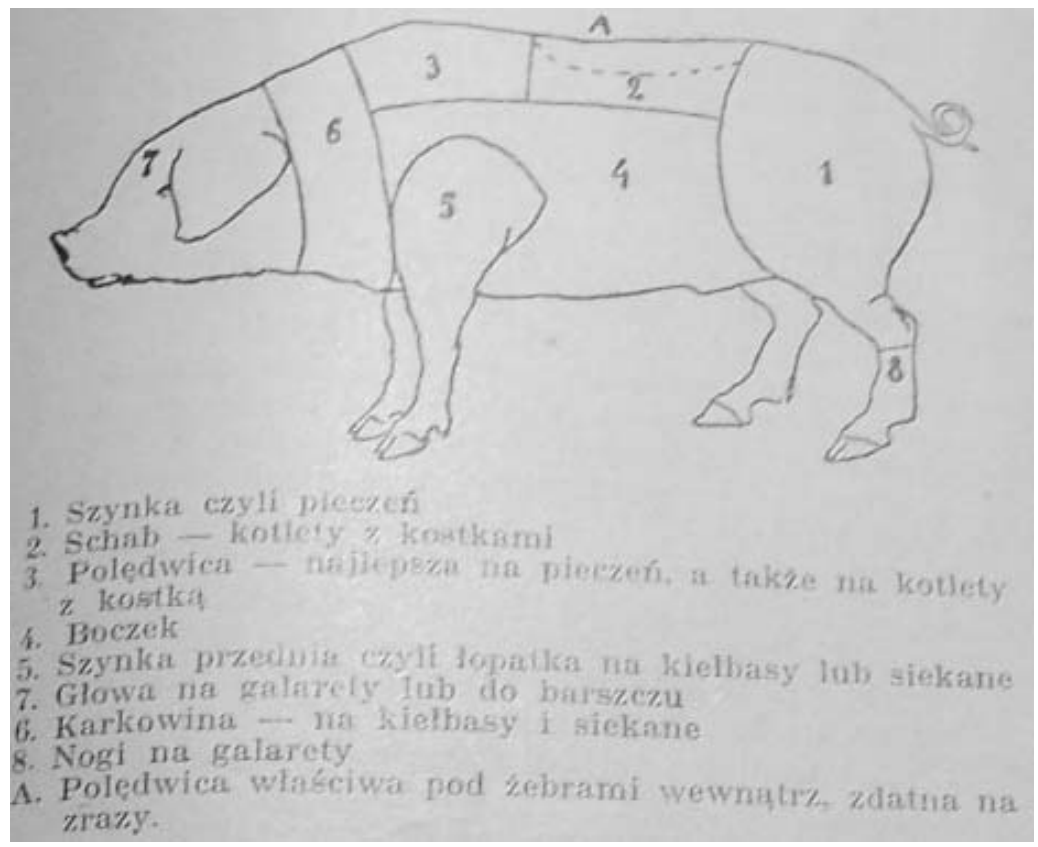

Ryc. 3. Podział mięsa wieprzowego ze względu na wykorzystanie poszczególnych porcji w przepisach kulinarnych.

Z gospodarstwa domowego: Przetwory mięsne, „Dobra Gospodyni” 1937, nr 2, s. 11

W przypadku opisu garbowania skór króliczych przekonywano czytelniczki, aby to pożyteczne zajęcie odbywało się przy udziale dzieci. W opinii autorki udzielającej porady w tym temacie

garbowanie skórek, rzecz nie taka trudna. Jest to praca lekka, wymagająca tylko dokładności. Przy odpowiednich wskazówkach wykonać ją mogą kilkunastoletni chłopcy. [...] Najłatwiej wyprawiać skórki natychmiast po zabiciu królika. Zdjętą skórkę rozcinamy ostrym nożem na brzuchu, starając się przeciąc prosto. Krzywo rozcięta ma brzydki kształt i trudniej potem coś z niej wykroić. Rozciętą skórkę przybijamy do deski sierścią do dołu w ten sposób, aby była mocno naciągnięta... ${ }^{27}$

${ }^{26}$ Dobra Gospodyni, O biciu wieprza i przyrzadzaniu wędlin, „Kobieta w Świecie i w Domu” 1928, nr 4, s. 12-13; Praktyczne przepisy: Urzqdzanie wieprza, „Dobra Gospodyni” 1931, nr 3, s. 7-8.

${ }^{27}$ M. Saryusz-Stokowska, Garbowanie skórek króliczych, „Dobra Gospodyni” 1931, nr 1, s. 2. 
Pracę w kuchni ułatwiała nie tylko jej dobra organizacja i racjonalne rozstawienie sprzętów kuchennych. Niebagatelnym ułatwieniem były nowoczesne urządzenia, które skracały czas pracy.

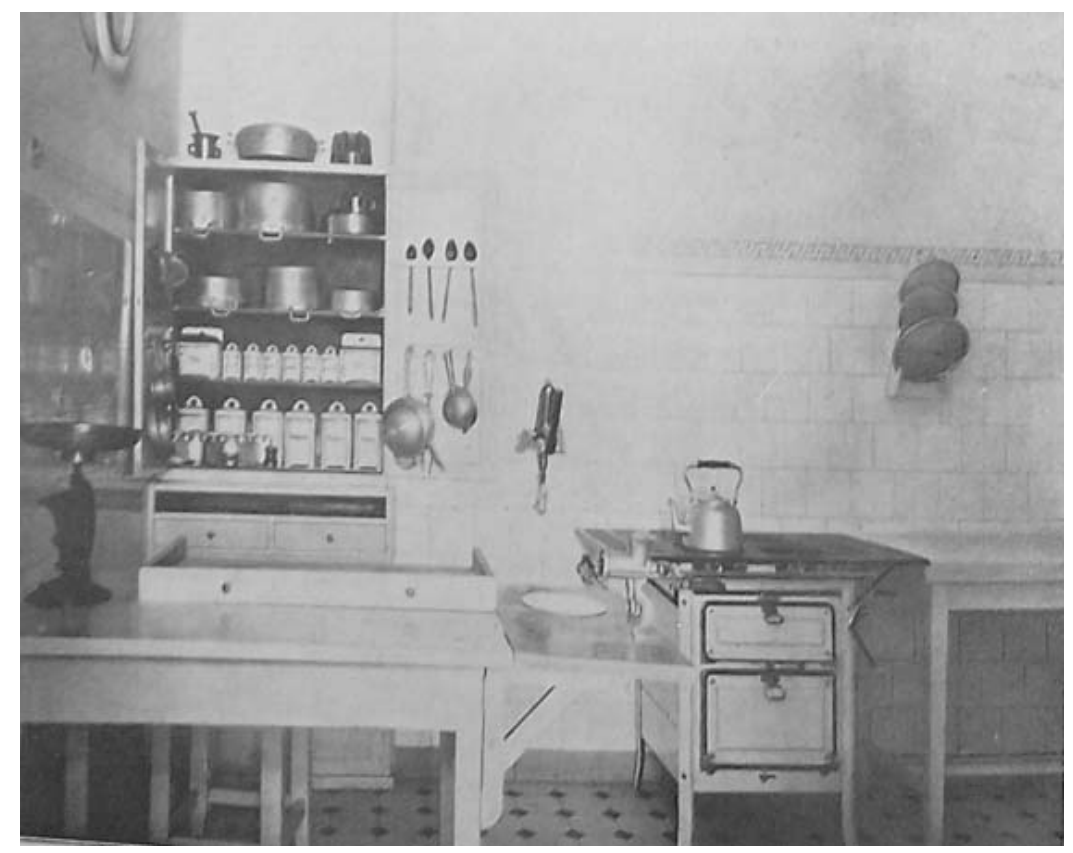

Ryc. 4. Przykład racjonalnie rozplanowanej kuchni z niezbędnymi przyborami kuchennymi.

I. Szumlakowska, Kuchnia, „Organizacja Gospodarstwa Domowego” 1929, nr 3, s. 36

Rola periodyków kobiecych $\mathrm{w}$ rozpowszechnianiu wiedzy na temat korzystania z nowoczesnych urządzeń gospodarstwa domowego była istotna. Redakcja „Organizacji Gospodarstwa Domowego” w dziale zatytułowanym „Do naszych wytwórców” prezentowała narzędzia, przyrządy, a nawet meble, które $\mathrm{w}$ jej opinii powinny być produkowane i masowo popularyzowane w każdym polskim domu. Przykładowo w numerze pierwszym z roku 1927 zostały zaprezentowane wzory „unowocześnionych śmietniczek, które dzięki swej konstrukcji umożliwiają zmiatanie śmieci bez nachylania się (ryc. 6, 7) ${ }^{28}$ :

Nieocenioną pomocą dla ówczesnych pań domu był rozwój techniczny w zakresie sprzętów gospodarczych. Maszyny do prania, suszarki do bielizny, odkurzacze, kuchnie gazowe, żelazka elektryczne i inne wynalazki, na pozór nieistotne $\mathrm{i}$ drobne, spowodowały rewolucyjne zmiany $\mathrm{w}$ prowadzeniu gospodarstwa domowego. Przez to zajęcia domowe nie wiązały już tak bardzo ko-

${ }^{28}$ Do naszych wytwórców, „Organizacja Gospodarstwa Domowego” 1927, nr 1, s. 9. Skan 6512. 


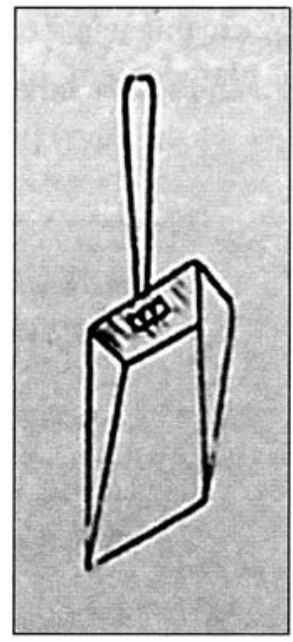

Ryc. 5. Śmietniczka powszechnie używana. Do naszych wytwórców, „Organizacja Gospodarstwa Domowego" 1927, nr 1, s. 9

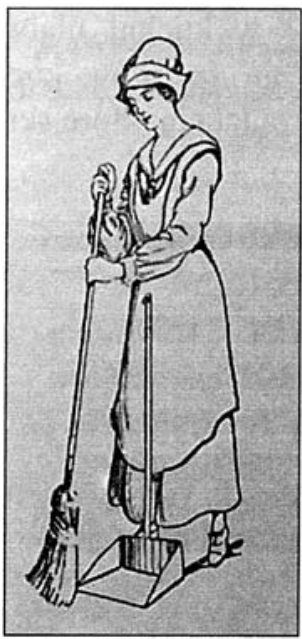

Ryc. 6. Najprostszy typ ulepszonej śmietniczki. Do naszych wytwórców, „Organizacja Gospodarstwa Domowego" 1927, nr 1, s. 9

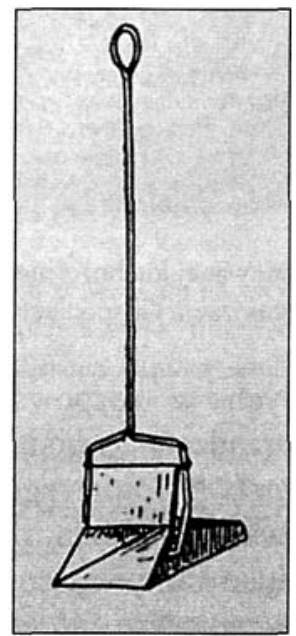

Ryc. 7. Nowoczesna śmietniczka, która przy podniesieniu zamyka się automatycznie.

Do naszych wytwórców, „Organizacja Gospodarstwa Domowego” 1927, nr 1, s. 9

biety, jak dawniej ${ }^{29}$. Niemniej, pozostawała kwestia możliwości nabycia tych sprzętów. Wszak dla wielu gospodarstw domowych, zwłaszcza w czasie kryzysu,

${ }^{29}$ Rozwój techniczny sprzętów gospodarczych był doceniany przez panie domu już w wieku XIX. Na przykład w latach sześćdziesiątych XIX stulecia coraz powszechniejsze stawały się maszyny do szycia, w drugiej zaś połowie lat sześćdziesiątych fabryka wyrobów żelaznych Karola Mintera w Warszawie zaczęła produkcję mechanicznych maszyn do prania. Pracę domową ówczesnych kobiet ułatwiały również takie urządzenia, jak rożen mechaniczny, maszynka do 
dostępność do nowinek technicznych była zbyt wielkim luksusem ${ }^{30}$. Tylko w najzamożniejszych gospodarstwach domowych codzienną pracę domową ułatwiały nowoczesne sprzęty gospodarstwa domowego. W Polsce międzywojennej nie tylko zresztą kwestia zasobności decydowała o korzystaniu z osiagnięć techniki. Poważnym utrudnieniem był słaby rozwój instalacji elektrycznych. Zwłaszcza w przypadku domostw wiejskich, znaczna część mieszkańców pozostawała poza zasięgiem elektryfikacji. Ponadto należy zaznaczyć, że ceny prądu były wysokie, więc mocno ograniczały dostęp do wykorzystania istniejących już instalacji. Podobnie rzecz miała się ze słabo rozwiniętą siecią instalacji wodociągowej. Brak bieżącej wody uniemożliwiał zaś korzystanie $\mathrm{z}$ takich wynalazków jak pralka ${ }^{31}$.

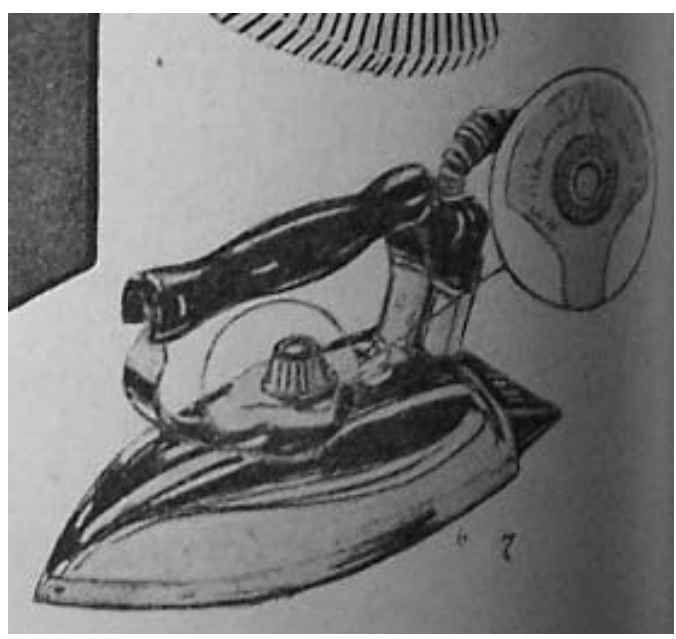

Ryc. 8. Elektryczne żelazko z regulatorem.

Z dziedziny ulepszeń gospodarskich, „Kobieta w Świecie i w Domu” 1930, nr 14, s. 16

palenia kawy, maszynka do kręcenia lodów, maszynka do mielenia mięsa, syfon do wody sodowej: E. Kowecka, Zmiana roli kobiety $w$ prowadzeniu domu $w$ XIX wieku, [w:] Kobieta i kultura życia codziennego; Wiek XIX i XX, red. A. Żarnowska, A. Szwarc, t. V, Warszawa 1997, s. 157. Oczywiście wynalazki techniczne w tej materii były w międzywojniu jeszcze bardziej spektakularne i w jeszcze większym stopniu ułatwiały kobietom pracę w gospodarstwie domowym. Rozwój nauki i techniki w sposób bezpośredni przekładał się na jakość życia pań domu. Zob.: Z. Chyra-Rolicz, Kobiety a unowocześnianie $i$ uspotecznianie gospodarstw domowych $w$ Polsce międzywojennej, [w:] Kobieta i kultura życia..., s. 249-264.

${ }^{30}$ Przykładowo cena najtańszego bojlera elektrycznego w 1936 r. wynosiła 150 zł, chłodziarki absorpcyjnej o pojemności $601 \mathrm{ok} .1400 \mathrm{zł}$, zarobki urzędnika średniego szczebla nie były zaś wówczas wyższe niż 300 zł. J. Żarnowski, Polska 1918-1939; Praca-technika-społeczeństwo, Warszawa 1992, s. 250.

${ }^{31}$ A. Janiak-Jasińska, Unowocześnianie gospodarstwa domowego $i$ wyposażenia mieszkań w Polsce międzywojennej, [w:] Równe prawa i nierówne szanse; Kobiety w Polsce międzywojen$n e j$, red. A. Żarnowska, A. Szwarc, Warszawa 2000, s. 202-203. 


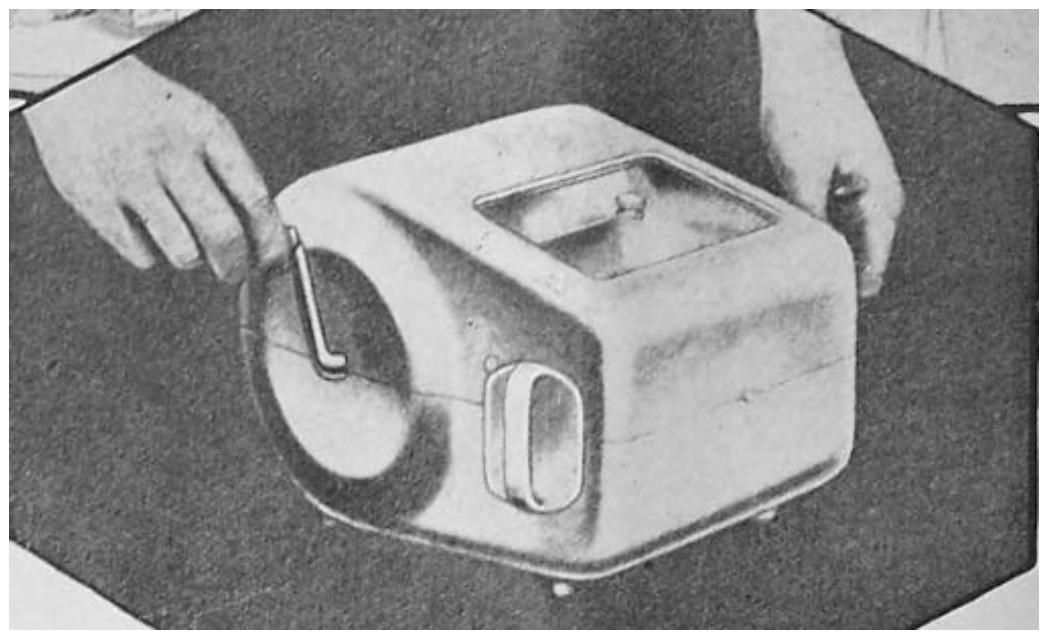

Ryc. 9. Maszynka do lodów.

Z dziedziny ulepszeń gospodarskich, ,Kobieta w Świecie i w Domu” 1930, nr 14, s. 16

Dla mniej zamożnych kobiet redakcje czasopism zamieszczały porady dotyczące samodzielnego wykonania ,wynalazków” ułatwiających prowadzenie gospodarstwa domowego. Czytelniczki „Organizacji Gospodarstwa Domowego" mogły dzięki dokładnym instrukcjom zrobić własny dogotowywacz, nieoceniony $\mathrm{w}$ długotrwałym gotowaniu potraw ${ }^{32}$. Także wiejskie panie domu na łamach „Dobrej Gospodyni” otrzymały przepis na zrobienie dogotowywacza:

Cały przyrząd składa się ze skrzynki drewnianej - dobrze wymoszczonej sianem, garnka z pokrywą i również sianem wypchanej poduszki. [...] wstawiony w siano garnek z gotującą się jakąś strawą, w ciagu kilku godzin utrzymuje temperaturę potrzebną do ugotowania danego posiłku i dlatego to po wstawieniu przy śniadaniu do dogotowywacza garnka z gotującą się zupą otrzymujemy ją już ugotowaną i zupełnie gorącą na obiad ${ }^{33}$.

W omawianych czasopismach kobiecych czytelniczki mogły znaleźć wiele ciekawych i praktycznych pomysłów na uatrakcyjnienie wnętrz mieszkalnych. Przykładowo w periodyku „Kobieta w Świecie i w Domu” zaproponowano im nowoczesne meble spełniające podwójną funkcję. Interesującą propozycją było podwieszane na łańcuchach łóżko, „które się na dzień podciaga do góry, zyskując w zamian ogromne lustro kryjące się pod spodem"34. Takie rozwiązania cenione były zwłaszcza $\mathrm{w}$ małych mieszkaniach, tym bardziej że w międzywojennej Polsce wciąż wzrastała liczba mieszkań jedno- i dwuizbowych ${ }^{35}$. Porady do-

\footnotetext{
${ }^{32}$ Dogotowywacz własnej roboty, „Organizacja Gospodarstwa Domowego” 1929, nr 1, s. 11.

${ }^{33}$ H. Gątkiewiczówna, Dogotowywacz, „Dobra Gospodyni” 1930, nr 6, s. 3-4.

${ }^{34}$ M. D., Nowoczesne meble, „Kobieta w Świecie i w Domu” 1930, nr 21, s. 19. Skan 9779.

${ }^{35}$ K. Krzeczkowski, Kwestia mieszkaniowa w miastach polskich, Warszawa 1939, s. 43-45.
} 
tyczące zwiększenia funkcjonalności wnętrz gościły często na łamach pism kobiecych. Redakcja „Pani Domu” popularyzowania nowoczesnych i racjonalnych rozwiązań w codzienności „kierowniczki” domu nie ograniczała wyłącznie do sprzętów AGD. Idea porządku i nowoczesności przyświecała również poradom związanym $\mathrm{z}$ fachową organizacją domowego księgozbioru. W tym celu przygotowała dla czytelniczek szybki kurs $\mathrm{z}$ podstaw projektowania minibiblioteki do użytku domowników. Informacje były wyczerpujące i merytoryczne. Nie bez znaczenia pozostawał fakt, że autorką artykułu była bibliotekarka ${ }^{36}$.

Niezależnie od tego, czy dane czasopismo kobiece było skierowane do czytelniczki mieszkającej na wsi czy w mieście pewien rodzaj porad miał ten sam charakter. Każda z kobiet szukała sprawdzonych przepisów na wywabianie plam $^{37}$, walczenie $\mathrm{z}$ kurzem ${ }^{38}$, sposobów na odetkanie zapchanego zlewu ${ }^{39}$, uratowanie przypalonego mleka ${ }^{40}$, prania odzieży $z$ włóczki, aby ta nie uległa zniszczeniu $^{41}$ bądź chciała poznać sekret udanych wypieków ${ }^{42}$. Różnice związane $\mathrm{z}$ poradnictwem domowym $\mathrm{w}$ czasopismach kobiecych dotyczyły problematyki związanej z pracą gospodyni wiejskiej. Dla nich głównym źródłem uzyskiwania dochodów była najczęściej hodowla zwierząt domowych, uprawa roli, ogrodnictwo czy sadownictwo. W związku z tym dbano o wysoki poziom merytoryczny artykułów poświęconych tej tematyce. Mieszkanki wsi prenumerując „Dobrą Gospodynię” otrzymywały specjalistyczną wiedzę o tym, jak np. powinny uprawiać kukurydzę ${ }^{43}$, sadzić drzewka owocowe ${ }^{44}$, walczyć z mszycą i grzybami niszczącymi sady ${ }^{45}$, rozpocząc hodowlę kur na nioski ${ }^{46}$, na czym polega tucz świñ ${ }^{47}$ czy odebranie porodu u krowy opisane szczegółowe przez instruktorkę Wielkopolskiej Izby Rolniczej ${ }^{48}$. Czasopisma kobiece skierowane do kobiet wiejskich szeroko omawiały problematykę związaną z pracą gospodyni wiejskiej. Nie tylko pisma stricte dla gospodyń wiejskich, takie jak

\footnotetext{
${ }^{36}$ M. Gutry, Organizacja księgozbioru domowego, „Pani Domu” 1932, nr 1, s. $2-4$.

${ }^{37}$ W. Kączkowski, O wywabianiu plam, „Pani Domu” 1935, nr 2, s. 36.

${ }^{38}$ T. Skorzewska, Walczmy z kurzem, „Organizacja Gospodarstwa Domowego” 1928, nr 8,
} s. 121.

${ }^{39}$ A. Jawidzykowa, Zapychanie się zlewów, „Pani Domu” 1933, nr 2, s. 35.

${ }^{40}$ Praktyczne przepisy: Jak przywrócić przypalonemu mleku dobry smak, „Dobra Gospodyni" 1929, nr 11, s. 7.

${ }^{41}$ Pranie włóczkowych rzeczy, „Praktyczna Pani - Dobra Obywatelka” 1939, nr 14, s. 23.

${ }^{42}$ M. Karczewska, Sekret udanego ciasta, „Pani Domu” 1933, nr 12, s. 237.

${ }^{43}$ Jak uprawiać kukurydzę na ziarno, „Dobra Gospodyni” 1928, nr 2-3, s. 15.

${ }^{44}$ M. Skornóg-Cikowska, O drzewach owocowych, „Dobra Gospodyni” 1932, nr 3, s. 1-2.

${ }^{45}$ Nieprzyjaciele sadu i walka z nimi, ,Dobra Gospodyni” 1930, nr 3, s. 3.

${ }^{46}$ Wychów kur na dobre nioski, „Dobra Gospodyni” 1929, nr 2, s. 4-5.

${ }^{47}$ Tani tucz świń, „Dobra Gospodyni” 1929, nr 11, s. 3-4.

48 J. Hulanicka, Pielęnacja i pomoc położnicza u krów, „Dobra Gospodyni” 1931, nr 4, s. $2-3$. 
„Dobra Gospodyni”, poruszały tematykę pracy gospodarczej. Niektóre, choć wydawane z myślą o kobietach mieszkających w miastach i miasteczkach, miały działy przeznaczone wyłącznie dla kobiet wiejskich ${ }^{49}$, tak jak to było w przypadku „Praktycznej Pani - Dobrej Obywatelki”. Ponadto w obydwu tych periodykach doradzano kobietom $\mathrm{w}$ sprawach wszystkich okresowych prac w gospodarstwie. Każdy miesiąc był przeznaczony na inne prace, które związane były z ogrodem, sadem, warzywnikiem, kurnikiem, chlewem, spiżarnią i domem. Tak szczegółowy plan pracy był charakterystyczny szczególnie dla czasopisma „Dobra Gospodyni”. W przypadku drugiego tytułu informacje dotyczyły określonej pracy $\mathrm{w}$ danym miesiącu, np. pasieki albo prac ogrodniczych.

Porady w czasopismach kobiecych, będących przedmiotem analizy przeprowadzonej na potrzeby niniejszego artykułu, odgrywały bardzo istotną rolę. Chociaż nie tylko w tym przypadku. Generalnie, cechą charakterystyczną dla periodyków kobiecych okresu międzywojennego były zagadnienia związane $\mathrm{z}$ szeroko rozumianym gospodarstwem domowym, ujmowane w tonie dobrych rad i praktycznych wskazówek. Należy podkreślić, że z punktu widzenia wydawcy niosły one ze sobą przekaz edukacyjny, ale były także istotną zachętą dla czytelniczek do zdecydowania się na prenumeratę periodyku. Dla nich bowiem otrzymywanie pisma z poradami odpowiednimi dla aktualnej pory roku było nie tylko przydatne na bieżąco. W wielu domach zbierano archiwalne numery, których kolekcja pełniła funkcję książki kucharskiej, podręcznika gospodarowania czy po prostu „ABC codzienności”. Do gromadzenia numerów zachęcała nawet redakcja „Dobrej Gospodyni”:

Pojedyńcze numery „Dobra Gospodyni” radzimy układać starannie w miejscu zabezpieczonym od zniszczenia, a po upływie roku dać oprawić w książkę. Zyska się przez to wygodny wgląd, gdy chodzi o radę lub przepis, oraz pomnożenie bibljoteczki domowej ${ }^{50}$.

Oprócz specyfiki problematyki związanej z gospodarstwem wiejskim, popularne były zwłaszcza porady związane z domem i kuchnia, czyli z dziedzinami życia, które pomimo emancypacji kobiet, stanowiły dla nich nadal istotną część zajęć codziennych. Redakcjom omawianych pism przyświecała ogólna idea, że nawet prozaiczne trudności związane z prowadzeniem domu zasługują na uwagę i praktyczne rozwiązanie. Zresztą udzielanie porad z zakresu prac domowych i gospodarczych leżało nie tylko w gestii redakcji czy dziennikarek, ale radzić czytelniczkom mogły również inne abonentki pisma.

${ }^{49}$ Mnożenie i sadzenie bylin, „Praktyczna Pani - Dobra Obywatelka” 1937, nr 34, s. 13; Rozplanowanie ogródka warzywnego, „Praktyczna Pani - Dobra Obywatelka” 1939, nr 7, s. 19; Choroby drobiu, „Praktyczna Pani - Dobra Obywatelka” 1937, nr 30, s. 17 i in.

${ }^{50}$ Od Redakcji, „Dobra Gospodyni” 1928, nr 2-3, s. 23. 